\title{
Impact of Economic Policy Uncertainty and Macroeconomic Factors on Stock Market Volatility: Evidence from Islamic Indices
}

\author{
Tariq AZIZ ${ }^{1}$, Jahanzeb MARWAT ${ }^{2}$, Sheraz MUSTAFA ${ }^{3}$, Vikesh KUMAR ${ }^{4}$
}

Received: September 01, 2020 Revised: October 26, 2020 Accepted: November 16, 2020

\begin{abstract}
The primary purpose of the study is to investigate the volatility spillovers from global economic policy uncertainty and macroeconomic factors to the Islamic stock market returns. The study focuses on the Islamic stock indices of emerging economies including Indonesia, Malaysia, and Turkey. The Macroeconomic factors are industrial production, consumer price index, exchange rate. EGARCH model is employed for investigation of volatility spillovers. The results show that the global economic policy uncertainty has a significant spillover effect only on the returns of Turkish Islamic stock index. Similarly, the shocks in macroeconomic factors have little influence on the volatility of Islamic indices returns. The volatility of Indonesian and the Turkish Islamic stock indices returns is not influenced from the fluctuations in macroeconomic factors. However, there is significant volatility spillover only from industrial production to the returns of Malaysian Islamic index. The results suggest that the Islamic stock markets are less likely to influence from the global economic policies and macroeconomic factors. The stability of Islamic stocks provide opportunity for diversification of portfolios, particularly in stressed market conditions. The major price factors of Islamic markets could be firms' specific factors or investors' behaviors. The findings are helpful for policy makers and investors in formulating policies and portfolios.
\end{abstract}

Keywords: Islamic Stocks, Market Returns, Volatility Spillovers, Macroeconomic Variables

JEL Classification Code: C32, G15, O57

\section{Introduction}

Since the past two decades, empirical literature of financial economics focused on testing the hypothesis which describes that macroeconomics variables affect stock market behavior. Fama (1981), Geske and Roll (1983), Pearce and Roley (1984), and Chen, Roll, and Ross (1986) have done the pioneering studies that investigate the association

${ }^{1}$ First Author and Corresponding Author. Assistant Professor of Finance and Accounting, Sukkur IBA University, Sukkur, Pakistan [Postal Address: Airport Road Sukkur, Sindh, Pakistan]

Email: tariqazizsial@gmail.com

${ }^{2} \mathrm{PhD}$ Scholar, Sukkur IBA University, Sukkur, Pakistan.

Email: jahanzeb.phdmgt18@iba-suk.edu.pk

${ }^{3}$ Assistant Professor of Economics, Sukkur IBA University, Sukkur,

Pakistan. Email: sheraz.mustafa@iba-suk.edu.pk

${ }^{4}$ Lecturer, Sukkur IBA University, Sukkur, Pakistan.

Email: vikeshkumar@iba-suk.edu.pk

(c) Copyright: The Author(s)

This is an Open Access article distributed under the terms of the Creative Commons Attribution Non-Commercial License (https://creativecommons.org/licenses/by-nc/4.0/) which permits unrestricted non-commercial use, distribution, and reproduction in any medium, provided the original work is properly cited. of macroeconomic factors with stock market returns and argue that macroeconomic factors of a country influence the cash flows and policies of companies. Similarly, many other studies such as, Hamao (1988), Chen (1991), Poon and Taylor (1992), Maysami and Koh (2000), Flannery and Protopapadakis (2002), Arienzo et al. (2006), Sakti and Harun (2015), Hussin, Muhammad, Hussin, and Razak (2012), Aysan, Disli, and Ozturk (2018), Ulev and Aydın (2019), and Szczygielski, Brümmer, Wolmarans, and Zaremba (2020) have also examined the relationship between macroeconomic factors and stock market returns. However, this empirical work still lags behind the theoretical strength of the hypothesis that describes the relationship between macroeconomic factors and stock market returns. Because the empirical literature provides mix results that are also sensitive to context, sample period, and research methodology.

The current study focuses on the emerging Islamic economies to test the Macroeconomic-Returns hypothesis because literature has mostly concentrated on developed economies. More specifically, the study's sample includes the economies of Malaysia, Indonesia, and Turkey to 
analyze the impact of local and foreign macroeconomic variables like Industrial Production (IP), Consumer Price Index (CPI), Exchange Rate (ER), and Global Economic Policy Uncertainty (GEPU) on Stock Returns (SR).

The study analyzes the historical data of Islamic indices of the Islamic countries because the Islamic markets' development curves are continuously increasing and have been able to attract the flow of funds from International Muslim and non-Muslim Investors during last few decades (Ho, Rahman, Yusuf, \& Zamzamin, 2014). Further, the behavior of Islamic economies may be different from the other economies. Shamsuddin (2014) reported that Islamic finance is based on (Sharia) Islamic Principle laws that means interest (Riba) will not be used in any of the financial transactions, it is completely prohibited. In addition to that, (Gharar) which means excessive risk-taking, is also prohibited, and finally the worst of all is (Maysir) gambling, which can ruin the lives of even the wealthier, is also prohibited because of its risk and unethical quality. Islamic Finance promotes the Asset backed transactions and it also promotes the concept of risk-sharing by all the parties that are involved in the transactions.

The results of EGARCH model show that the spillover effects of macroeconomic factors on the stock market returns are different for the three Islamic stock indices. In the case of Malaysian Islamic stock index only Industrial production has significant spillover effect whereas in the context of Turkey only global economic policy uncertainty has a significant volatility spillover effect on the Islamic stock index. However, the volatility of stock market returns of Indonesian Islamic stock index does not influence from the shocks of macroeconomic factors.

The findings contribute to literature in three ways. Firstly, it provides an updated evidence of volatility spillover from macroeconomic factors to the Islamic stock market returns. Secondly, the study focuses on emerging Islamic economies that lack in literature and only few studies considered the Islamic indices of emerging countries to examine the volatility spillover from macroeconomic factors to stock market returns. Thirdly, the study uses EGARCH model to investigate the volatility spillovers that are most appropriate and allows for asymmetry. However, literature mostly used other linear or dynamic models.

The remaining paper is distributed as: the second section is literature review that discuss and analyzes the literature. The Third section is about methodology that describes the research methodology including data and sample, variables measurement, pre-estimation data analysis, and econometric model. Fourth section namely Results and discussion provides results and discussions of the econometric models. The last section is conclusion that provides concluding remarks of the study.

\section{Literature Review}

The concept of global market integration has become a hot topic for the last few decades (Barberis, Shleifer, \& Wurgler, 2005). The uncertainty of a country influences the markets of other countries depending upon the size and strength of economies (Bhattarai, Chatterjee, \& Park, 2019; Jeon, 2018). For example, the Han, Liu, and Yin (2019) documented that US is a larger economy and its uncertainty significantly depreciates the weak currencies, however, the strong currencies remain stable. Further, the spillover effect among different economies has become more dominant after the recent financial crisis (McIver $\&$ Kang, 2020). In the crises period mostly international investors withdraw their capital and search for safe-haven assets such as international investors trading volume in Thailand declined in the crisis of COVID-19 (Anya, 2020).

The concept of Islamic equity indices has also attracted many investors because they are subjected to measure the business activities, purification of dividends and financial ratios which are being used to measure the public shariacompliant firm's performance. Naifar (2016) shows that this development in Islamic equity indices has provided market gape to many banks and investment firms to provide opportunity to many investors who want to invest their money with sharia principles. In banking sectors also customers have more trust in Islamic banks as compared to conventional banks (Hardius, 2015). Therefore, according to the world bank statistics, Islamic banks/Islamic equity spread around world-wide in both Islamic and Non-Islamic countries (Nurodin, Lilik, \& Bagus, 2019).

Emerging markets like Malaysia has two Islamic Indices. Firstly, Rashid Hussain Berhad Islamic (RHBI) index. Secondly, Kuala Lumpur Shariah Index KLSI based on main board companies which was introduced in 1999 and worked as key metrics for measuring shariah approved securities performance. The index also helps people who want to invest based on Shairah principles. On June 23, 2005, RHBI Islamic Index was replaced by Dow JonesRHB Islamic Malaysia Index. It was introduced by one of the world's best index Dow Jones Indexes and RHB Research Institute Sdn Bhd with only intent to meet the demand of Sharia's compliance (Majid \& Yusof, 2009).

In addition to that, emerging market like Indonesia have come up with the major development in Islamic equity indices which can be used as key metrics for investments and are Sharia-compliant. Jakarta Islamic Index (JII) was introduced on July 3rd, 2000. As time passes investors became doubtful if the investments in JII was Sharia Complaint. To overcome the doubts of the investors, Indonesia Stock Exchange introduced the Indonesia Sharia Stock Index (ISSI) on May 2nd, 2011 which eliminated doubts of investors and boosted the trading of Islamic 
Tariq AZIZ, Jahanzeb MARWAT, Sheraz MUSTAFA, Vikesh KUMAR /

Journal of Asian Finance, Economics and Business Vol 7 No 12 (2020) 683-692

stocks in Indonesia (Imron.et al). Other emerging markets like Turkey have developed their first Islamic index which is called the "DMI 150 index". It was introduced in 1998 with the help of Faisal Finance and Bank Vontebel. This Index use the key metrics of performance for 150 publicly traded global companies (Khamlichi, Sarkar, Arouri, \& Teulon, 2014).

Many researchers have analyzed the cointegration amongst the local Macroeconomic, Foreign macroeconomics factors that affect the Capital markets of different Islamic countries or Islamic capital markets. For example, Sakti and Harun (2015) showed that there exists cointegration between Macroeconomic factors like Industrial production, Exchange rate, money supply and inflation rate that affects Islamic stock prices. In addition to that Hammoudeh, Mensi, Reboredo, and Nguyen (2014) found that the (DJIMI) Index and macroeconomic factors like US 10 years' treasury bill, oil prices, treasury bond rate and EU Bond Index has positive relationship. Ajmi, Hammoudeh, Nguyen, and Sarafrazi (2014) found a linear but inverse relationship which caresses causality between the Islamic stock market and interest rates.

It has been observed that Islamic Financial market has been developed with the help of Islamic Indices but Investors believe that any development can't eliminate the influence of macroeconomics factors and their volatility on stock markets (Gan, Lee, Yong, \& Zhang, 2006). Macroeconomic factors are used as a benchmark by investors to predict the future performance of stock market (Talla, 2013). Gan et al. (2006) analyzed cointegration between macroeconomics factor namely CPI in NewZealand stock market index. Here CPI was considered because movement of index prices was considered by the investors while investing in stock market and this study showed that CPI and stock index are negatively related. Therefore, analysis of Islamic indices and relationship with macroeconomic factors is important because it might provide some results that would help to simulate the existence of Islamic Capital Market.

Jamaludin, Ismail, and Manaf (2017) have analyzed the economy of three Asian countries namely Singapore, Indonesia, Malaysia. They have measured impact of macro factors like Inflation, Exchange rate and Money supply on Islamic indices. In that study, they have come up with the results like Inflation, and exchange rate effects the Islamic indices but it is not being affected by the money supply. Habib and Islam (2017) used the Ordinarily least square (OLS) and studied the Indian Islamic stock market to analyze weather macro factors like Money Supply, Industrial production, Exchange rate, Inflation, and Interest rate impacts Islamic Indices of India? They have come up with results which are somewhat relevant to previous studies on Islamic Indices, Indian Islamic indices are affected by interest rate and exchange rate but it is not being affected by Inflation, Money supply and Industrial production by any mean.

Sakti and Harun (2015) studied cointegration between Jakarta Stock Exchange Islamic Index (JII), Indonesian Sharia Stock Index (ISSI) and macro factors like Exchange Rate, Inflation, IPI and Money Supply. When a country hits a high inflation cointegration between Inflation and ISSI can be analyzed by the economic situation because it deprecates the local currency. Further positive linkages have been observed between IPI and Islamic Index. Wahyudi and Sani (2014) investigated the cointegration between macro factors and Islamic indices by using data from 2002 to 2011 . They found almost similar results to the previous Malaysian studies like Exchange rate affects the (JII) against the U.S. dollar and on the other side interest rate does not affect the JII.

Hussin et al. (2012) used monthly data from April 1999 to October 2007 and studied the relationship between Malaysian Islamic Indices and macro factors and they found positive cointegration between CPI, IPI and Islamic Indices but they found negative relationship between M3 and MYR variables. Yusof and Majid (2007) investigated relationship between Interest rate (affected by monetary policy) and Malaysian Islamic Indices sensitivity of stocks. They found that Interest rate (affected by monetary policy) does not affect the Malaysian Islamic Indices sensitivity of stocks. These results are familiar with other studies as well as all the macroeconomic variable significantly affects the Islamic index returns except Industrial production. Hussin et al. (2012) investigated cointegration between Islamic capital market of Malaysia and exchange rates, oil prices by using vector auto regression (VAR) methodology. They have come up with results which are quite understandable in the Islamic finance context, the results elaborated that oil prices have cointegration with Islamic indices, but it has an inverse correlation with exchange rate of Malaysia against US dollar.

Aysan et al. (2018) investigated the effect of interest rate sensitivity of both deposits and credits on Islamic and conventional banks in Turkey. Their finding showed that lending channels of Islamic banks are more operative, and depositors of Islamic banks are more sensitive to changes in monetary policy rate as compared to the conventional bank depositors. From this study it is obvious that tight monetary policy can cause the reduction of credits in Islamic banks. Ulev and Aydin (2019) have come up with similar study like Aysan et al. (2017) but with different companies and they studied the effect of interest rate on 30 Islamic index companies by using the panel data of 41 participant index companies from 2011 to 2017 and using LM bootstrap panel integration test. They have used Turkish government bonds which was traded in secondary 
markets as interest rate and results showed that interest rate impacts negatively to the stock prices of 30 index companies.

Hayat and Kraeussl (2011) studied the 145 Islamic equity funds (IEFs) by analyzing their risk and return characteristics over the period of 2000 to 2009 . They found that Islamic equity benchmarks are better than IEFs and IEFs that are underperformed. Ho et al. (2014) used crisis and non-crisis periods data from different countries at different time periods and they have analyses performance of 12 global Islamic Indices which are risk adjusted by using different performance measures of international portfolios like Treynor Index, Sharpe ratio, and best of them all is Jensen alpha has been used as well. Their results showed that Islamic indices are better performers during the crisis periods than the traditional stock indices. Jawadi, Jawadi, and Louhichi (2014) investigated the three major regions including Europe, USA, and World. They analyzed financial performance of conventional and Islamic Indices from 2000 to 2011 and they found that during the subprime mortgage financial crisis of USA, Islamic Indices were better performers than the conventional Indices which were better before the crisis.

However, some studies provided the mixed results on the performance analysis of Islamic indices because they might have used different performance measures like different benchmarks, different sample data and so on. For example, Atta (2000) and Hassan (2001) investigated market and risk-free rate against the performance of (DJIM). They found that DJIM has performed better than its conventional counterparts and they have also found that it offered more returns as compared to risk free rate. On the contrary, Hassan and Girard (2010) used different performance measure which was Single factor CAPM to four factor conditional CAPM to check the validity of results that he found about performance of Dow Jones Islamic Indices against the 7 Morgan and Stanly conventional indices by using the data from 1996 to 2005. Their results have shown that there is no significant difference in the performance of both indices. They have also found that core drivers of positive performance of Islamic Indices are small and growth stocks. About the performance of Saudi Arabia Islamic Indices same results are reported by Dabeerru (2006). He reports that performance of Saudi Islamic Indices does not depend on the Shariah screenings and it does not lead to good performance of Islamic Indices.

In summary of the above discussion, it can be concluded that the literature provides mixed results about the relationship between macroeconomic factors and the Islamic stock indices. The differences in findings of different studies might be attributed to the differences in research methodologies, sample periods and data frequencies. Further, governments continuously make amendments in policies and regulations that also influence financial decisions of firms. The shocks in international markets, political relationships with other countries, and global factors also influence the local markets. Therefore, the current study attempts to provide updated evidence of the relationship between macroeconomic factors and Islamic stock indices.

\section{Methodology}

\subsection{Data and Variables}

The study focuses on three major Islamic indices of three Islamic countries. Indonesia Islamic Index, Hijara Shariah Index, and Dow Jones Islamic market, Turkey that are operating in Indonesia, Malaysia, and Turkey, respectively. The macroeconomic factors are included Industrial production, Consumer Price Index (CPI) that measures the inflation, and Exchange Rate (ER) that are selected based on literature. Monthly historical data of the three indices and the macroeconomic factors of all the countries, for the period December 2010 to September 2019 is used for empirical analysis. The data source is Bloomberg.

The stock market returns are the log returns that are calculated as natural $\log$ of $\left(\mathrm{P}_{\mathrm{t}}-\mathrm{P}_{\mathrm{t}-1} / \mathrm{P}_{\mathrm{t}-1}\right)$ where $\mathrm{P}_{\mathrm{t}}$ is the stock price of the current month and $\mathrm{P}_{\mathrm{t}-1}$ is the stock price of the previous month.

\subsection{Unit Root Test}

Unit root test provide information about the stationarity of a data distribution that is very important before selection of econometric models for analysis. Because the behavior of stationary and non-stationary series is quite different from each other. Further, the treatments of both types of distribution is also different. For fair results, the study uses two different unit root test including Augmented Dickey Fuller test (ADF) and Phillips Perron test (PP). The results of the test for all the countries are summarized in table 1 . The results of both the tests show that all the variables are stationary at first difference.

\subsection{Econometric Model}

Keeping in view the above pre-estimation analysis, EGARCH $(1,1)$ model is employed to investigate the volatility spillover of macroeconomic factors on the stock market returns of the Islamic indices. EGARCH model allows for asymmetric effects of positive and negative shocks that was developed by Nelson (1991). The algebraic representation of the model is given below: 
Tariq AZIZ, Jahanzeb MARWAT, Sheraz MUSTAFA, Vikesh KUMAR /

Table 1: Unit Root Tests

\begin{tabular}{|l|c|c|c|c|}
\hline & \multicolumn{2}{|c|}{ ADF } & \multicolumn{2}{c|}{ PP } \\
\hline & Level & $1^{\text {st }}$ Diff & Level & $1^{\text {st }}$ Diff \\
\hline Indonesia & & & & \\
\hline SP & -2.16 & $-11.45^{*}$ & -2.16 & $-11.45^{*}$ \\
\hline CPI & -1 & $-11.17^{*}$ & -1.15 & $-17.55^{*}$ \\
\hline ER & 0.02 & $-10.04^{*}$ & 0.24 & $-7.79^{*}$ \\
\hline Malaysia & -0.07 & $-8.67^{*}$ & -0.34 & $-8.62^{*}$ \\
\hline SP & 1.11 & $-11.26^{*}$ & 1.2 & $-11.26^{*}$ \\
\hline IP & 4.89 & $-5.68^{*}$ & 3.52 & $-25.78^{*}$ \\
\hline CPI & 4.94 & $-8.25^{*}$ & 5.26 & $-8.29^{*}$ \\
\hline ER & 0.44 & $-8.04^{*}$ & 0.53 & $-8.04^{*}$ \\
\hline Turkey & & & & \\
\hline SP & 1.29 & $-12.69^{*}$ & 2.13 & $-12.67^{*}$ \\
\hline IP & 3.19 & $-2.14^{*}$ & 0.53 & $-30.47^{*}$ \\
\hline CPI & 4.95 & $-2.10^{*}$ & 8.84 & $-6.01^{*}$ \\
\hline ER & 2.67 & $-8.76^{*}$ & 3.01 & $-7.18^{*}$ \\
\hline
\end{tabular}

The table summarizes the results of two different unit root tests including Augmented Dickey Fuller Test (ADF) and Phillips Perron test (PP). Stock market returns (SP), Industrial production (IP), Consumer price index (CPI), and Exchange rate (ER) are the macroeconomic factors. The stars $\left({ }^{*}\right)$ shows the significance of the test statistics of the corresponding test. The results are shown separately for the three countries including Indonesia, Malaysia, and Turkey.

$$
\begin{aligned}
y_{\mathrm{t}}=\mu & +\delta y_{\mathrm{t}-1}+u_{\mathrm{t}}, u_{t} \sim N\left(0, \delta_{t}^{2}\right) \\
\ln \left(\delta_{t}^{2}\right) & =\omega+\alpha \ln \left(\delta_{t-1}^{2}\right)+\gamma \frac{u_{t-1}}{\sqrt{\delta_{t-1}^{2}}} \\
& +\beta\left[\frac{\left|u_{t-1}\right|}{\sqrt{\delta_{t-1}^{2}}}-\sqrt{\frac{2}{\pi}}\right]+\rho \text { Volatality }
\end{aligned}
$$

Where, $\ln \left(\delta_{t(A)}^{2}\right)$ is the natural log of conditional volatility of stock market returns. $\alpha$ is the coefficient of ARCH term. $\gamma$ shows the leverage effect or asymmetric effect of positive and negative news. $\beta$ is the coefficient of GARCH term. $\rho$ measures the volatility spillover from the macroeconomic indicators to the stock market returns of the Islamic indices. The model is used separately for each macroeconomic factor and each country.

\section{Results and Discussion}

\subsection{Descriptive Statistics}

Descriptive statistics provide the nature and characteristics of the data distributions. More specifically, it provides the average values, extreme values, spread, and normality of a data distribution. Table 2 summarizes the descriptive statistics of all the variables for all the countries.

The table shows that the mean values of the stock returns are $0.91,0.52$, and 0.97 for the Islamic index of Indonesia, Malaysia, and Turkey, respectively. It means, on an average the stock prices are growing during the sample period for all the indices. The performance of Indonesia and Turkey Islamic indices is better compared to the Islamic stock market of Malaysia. However, Turkey Islamic stock index is more stable than the other two indices as it has the lowest standard deviation. The Jarque Bera test shows that the data of only stock market of Turkey is normally distributed. The trend lines of stock prices of all the three Islamic stock indices are shown in Figure 1.

The table also shows that the mean values of all the macroeconomic factors are positive for all the countries. The Turkey has higher mean values of industrial production and exchange rate, but it also has higher inflation and lower stability of economy than other two countries.

\subsection{Correlation Matrix}

Correlation matrix is important to know about the relationship between a pair of variables. However, it does not tell about the causality. Further, correlation also provides information about the multicollinearity between two variables. If two variables have a higher correlation (generally more than 0.9 ), then they will cause multicollinearity problems in regression models. Table 3 shows the correlation matrix for all the countries. The correlation coefficient is low in the context of each country that indicates there is no issue of multicollinearity. Further, inflation and exchange rate have negative correlation with stock market returns in the case of all countries.

\subsection{Results of EGARCH Model}

The results of the EGARCH $(1,1)$ model are summarized in table 4. The table shows that the coefficient of $\mathrm{ARCH}$ term $\alpha$ is negative and significant for all the macroeconomic indicators except ER for Indonesian Islamic index. It indicates that size of the shocks influence the stock market volatility. Larger the size of the shocks, lower will be the future volatility. The coefficient of leverage term $\gamma$ is positive but significant only for the macroeconomic factors IP and CPI. The positive and significant coefficient of leverage term shows that positive shocks increase the future volatility more than the negative shocks. 
Table 2: Descriptive statistics

\begin{tabular}{|l|c|c|c|c|}
\hline & SP & IP & CPI & ER \\
\hline Indonesia & & & & \\
\hline Mean & 0.91 & 0.14 & 0.37 & 0.17 \\
\hline Median & 1.19 & 0.38 & 0.21 & 0.14 \\
\hline Maximum & 22.75 & 15.10 & 2.97 & 7.06 \\
\hline Minimum & -10.66 & -29.42 & -0.45 & -7.61 \\
\hline Std.Dev & 5.01 & 4.84 & 0.47 & 1.97 \\
\hline Skewness & 0.38 & -2.03 & 2.01 & -0.19 \\
\hline Kurtosis & 5.60 & 15.30 & 10.81 & 5.96 \\
\hline Jarque-Bera & 39.63 & 903.70 & 416.15 & 48.20 \\
\hline Probability & 0.00 & 0.00 & 0.00 & 0.00 \\
\hline Malaysia & & & & \\
\hline Mean & 0.52 & 0.27 & 0.16 & 0.12 \\
\hline Median & 0.61 & 0.17 & 0.17 & 0.00 \\
\hline Maximum & 11.98 & 14.16 & 1.80 & 6.61 \\
\hline Minimum & -8.92 & -12.31 & -1.24 & -4.51 \\
\hline Std.Dev & 2.92 & 4.82 & 0.36 & 1.85 \\
\hline Skewness & -0.05 & 0.12 & 0.35 & 0.55 \\
\hline Kurtosis & 5.27 & 3.73 & 8.31 & 4.06 \\
\hline Jarque-Bera & 27.89 & 3.25 & 154.47 & 12.68 \\
\hline Probability & 0.00 & 0.19 & 0.00 & 0.00 \\
\hline Turkey & & & & \\
\hline Mean & 0.97 & 0.44 & 0.74 & 1.01 \\
\hline Median & 1.81 & 0.32 & 0.57 & 1.02 \\
\hline Maximum & 11.89 & 21.64 & 6.11 & 19.97 \\
\hline Minimum & -11.71 & -24.71 & -1.45 & -8.37 \\
\hline Std.Dev & 5.27 & 10.42 & 0.95 & 3.54 \\
\hline Skewness & -0.40 & -0.28 & 1.51 & 1.06 \\
\hline Kurtosis & 2.66 & 2.74 & 9.63 & 8.47 \\
\hline Jarque-Bera & 4.21 & 2.16 & 285.97 & 185.46 \\
\hline Probability & 0.12 & 0.33 & 0.00 & 0.00 \\
\hline The & & & \\
\hline
\end{tabular}

The table shows descriptive statistics of the variables including Stock market returns (SP), Industrial production (IP), Consumer price index (CPI), and Exchange rate (ER). All the variables are calculated as natural log of $\left(\mathrm{V}_{\mathrm{t}}-\mathrm{V}_{\mathrm{t}-1} / \mathrm{V}_{\mathrm{t}-1}\right)$ where $\mathrm{V}_{\mathrm{t}}$ and $\mathrm{V}_{\mathrm{t}-1}$ are the current month and previous month values of the corresponding variables. The descriptive statistics are shown separately for three countries including Indonesia, Malaysia, and Turkey.
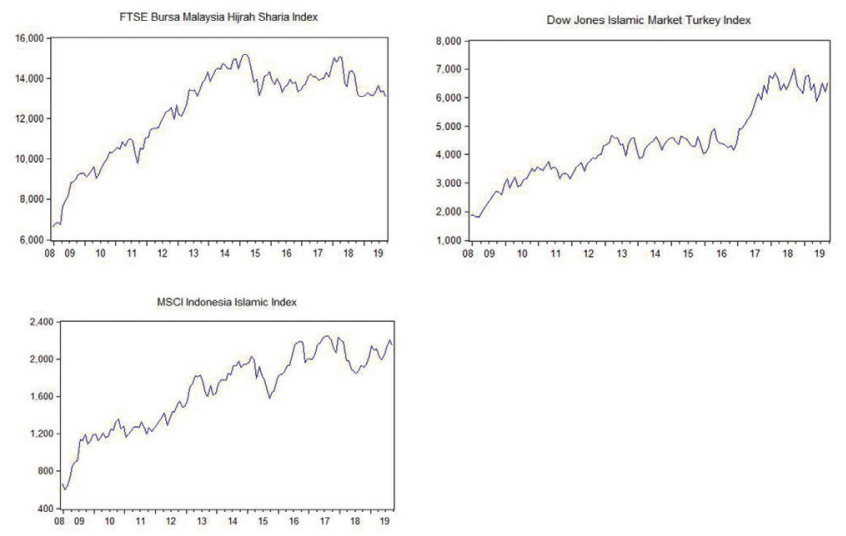

Figure 1: The trend lines of stock prices of all the three Islamic stock indices

Table 3: Correlation

\begin{tabular}{|l|c|c|c|c|c|}
\hline & SP & IP & CPI & ER & GEPU \\
\hline Indonesia & & & & & \\
\hline SP & 1 & & & & \\
\hline IP & 0 & 1 & & & \\
\hline CPI & -0.05 & -0.12 & 1 & & \\
\hline ER & -0.31 & 0.09 & 0.13 & 1 & \\
\hline GEPU & -0.14 & -0.01 & 0.06 & 0.2 & 1 \\
\hline Malaysia & & & & & \\
\hline SP & 1 & & & & \\
\hline IP & 0.13 & 1 & & & \\
\hline CPI & -0.11 & -0.14 & 1 & & \\
\hline ER & -0.24 & 0.08 & -0.05 & 1 & \\
\hline GEPU & -0.2 & 0.3 & -0.01 & 0.21 & 1 \\
\hline Turkey & & & & & \\
\hline SP & 1 & & & & \\
\hline IP & 0.04 & 1 & & & \\
\hline CPI & -0.07 & -0.05 & 1 & & \\
\hline ER & -0.19 & 0.01 & -0.13 & 1 & \\
\hline GEPU & 0.24 & 0 & -0.06 & 0.1 & 1 \\
\hline
\end{tabular}

The table shows Pearson correlation coefficient between the two variables. All the variables i.e Stock market returns (SP), Industrial production (IP), Consumer price index (CPI), Exchange rate (ER), and Global economic policy uncertainty (GEPU), are calculated as natural log of $\left(\mathrm{V}_{\mathrm{t}}-\mathrm{V}_{\mathrm{t}-1} / \mathrm{V}_{\mathrm{t}-1}\right)$ where $\mathrm{V}_{\mathrm{t}}$ and $\mathrm{V}_{\mathrm{t}-1}$ are the current month and previous month values of the corresponding variables. 
Table 4: Volatility Spillover (EGARCH -Bivariate)

\begin{tabular}{|c|c|c|c|c|}
\hline Indonesia & IP & CPI & ER & GEPU \\
\hline$\omega$ & $\begin{array}{c}0.43^{\star * *} \\
(0.00)\end{array}$ & $\begin{array}{c}0.37^{* * *} \\
(0.00)\end{array}$ & $\begin{array}{c}3.75^{\star \star *} \\
(0.00)\end{array}$ & $\begin{array}{c}0.37^{* * *} \\
(0.00)\end{array}$ \\
\hline$\alpha$ & $\begin{array}{c}-0.29 \\
(0.00)\end{array}$ & $\begin{array}{c}-0.27^{* * *} \\
(0.00)\end{array}$ & $\begin{array}{c}-0.15 \\
(0.34) \\
\end{array}$ & $\begin{array}{c}-0.26^{* * *} \\
(0.00)\end{array}$ \\
\hline Y & $\begin{array}{c}0.12 \\
(0.00) \\
\end{array}$ & $\begin{array}{l}0.091 \\
(0.02) \\
\end{array}$ & $\begin{array}{c}0.12 \\
(0.46) \\
\end{array}$ & $\begin{array}{c}0.05 \\
(0.10) \\
\end{array}$ \\
\hline$\beta$ & $\begin{array}{c}0.93^{* * *} \\
(0.00)\end{array}$ & $\begin{array}{c}0.93^{* * *} \\
(0.00)\end{array}$ & $\begin{array}{l}-0.13 \\
(0.62) \\
\end{array}$ & $\begin{array}{c}0.93^{* * *} \\
(0.00)\end{array}$ \\
\hline$\rho$ & $\begin{array}{c}0.01 \\
(0.23)\end{array}$ & $\begin{array}{c}0.08 \\
(0.18)\end{array}$ & $\begin{array}{l}-0.05 \\
(0.35)\end{array}$ & $\begin{array}{l}-0.00 \\
(0.77)\end{array}$ \\
\hline LL & -371.68 & -371.79 & -389 & -372.26 \\
\hline SS & 5.98 & 5.99 & 6.25 & 5.99 \\
\hline \multicolumn{5}{|l|}{ Malaysia } \\
\hline$\omega$ & $\begin{array}{l}0.49^{* *} \\
(0.03) \\
\end{array}$ & $\begin{array}{l}1.88^{* *} \\
(0.01) \\
\end{array}$ & $\begin{array}{l}2.14^{* *} \\
(0.04) \\
\end{array}$ & $\begin{array}{l}1.94^{*} \\
(0.06) \\
\end{array}$ \\
\hline$\alpha$ & $\begin{array}{l}-0.14 \\
(0.17) \\
\end{array}$ & $\begin{array}{c}-0.04 \\
(0.81) \\
\end{array}$ & $\begin{array}{c}0.01 \\
(0.93) \\
\end{array}$ & $\begin{array}{c}0.00 \\
(0.98) \\
\end{array}$ \\
\hline Y & $\begin{array}{l}-0.10^{*} \\
(0.07)\end{array}$ & $\begin{array}{l}-0.17 \\
(0.17) \\
\end{array}$ & $\begin{array}{c}-0.14 \\
(0.35) \\
\end{array}$ & $\begin{array}{c}-0.18 \\
(0.20) \\
\end{array}$ \\
\hline$\beta$ & $\begin{array}{c}0.78^{* * *} \\
(0.00)\end{array}$ & $\begin{array}{c}0.15 \\
(0.66) \\
\end{array}$ & $\begin{array}{l}-0.03 \\
(0.95) \\
\end{array}$ & $\begin{array}{c}0.07 \\
(0.88) \\
\end{array}$ \\
\hline$\rho$ & $\begin{array}{c}0.14^{* * *} \\
(0.00)\end{array}$ & $\begin{array}{l}-0.46 \\
(0.26)\end{array}$ & $\begin{array}{c}0.08 \\
(0.16) \\
\end{array}$ & $\begin{array}{c}0.00 \\
(0.41) \\
\end{array}$ \\
\hline LL & -312.46 & -319.24 & -319.03 & -319.51 \\
\hline SS & 5.07 & 5.17 & 5.17 & 5.17 \\
\hline \multicolumn{5}{|l|}{ Turkey } \\
\hline$\omega$ & $\begin{array}{c}6.21^{* * *} \\
(0.00)\end{array}$ & $\begin{array}{c}6.27^{* * *} \\
(0.00)\end{array}$ & $\begin{array}{c}5.90^{\star * *} \\
(0.00)\end{array}$ & $\begin{array}{c}6.01^{* * *} \\
(0.00)\end{array}$ \\
\hline$\alpha$ & $\begin{array}{c}-0.08 \\
(0.59)\end{array}$ & $\begin{array}{c}-0.13 \\
(0.43)\end{array}$ & $\begin{array}{c}-0.14 \\
(0.43) \\
\end{array}$ & $\begin{array}{l}-0.08 \\
(0.55) \\
\end{array}$ \\
\hline Y & $\begin{array}{l}-0.19 \\
(0.13)\end{array}$ & $\begin{array}{l}-0.17 \\
(0.13)\end{array}$ & $\begin{array}{l}-0.17 \\
(0.18)\end{array}$ & $\begin{array}{l}-0.25^{*} \\
(0.04)\end{array}$ \\
\hline$\beta$ & $\begin{array}{c}-0.88^{* * *} \\
(0.00)\end{array}$ & $\begin{array}{c}-0.87^{* * *} \\
(0.00)\end{array}$ & $\begin{array}{c}-0.79^{* * *} \\
(0.00)\end{array}$ & $\begin{array}{c}-0.85^{\star * *} \\
(0.00)\end{array}$ \\
\hline$\rho$ & $\begin{array}{l}-0.00 \\
(0.44)\end{array}$ & $\begin{array}{r}-0.027 \\
(0.65)\end{array}$ & $\begin{array}{c}0.05 \\
(0.18)\end{array}$ & $\begin{array}{l}0.01^{* *} \\
(0.03)\end{array}$ \\
\hline LL & -394.76 & -395.13 & -394.28 & -391.46 \\
\hline SS & 6.34 & 6.35 & 6.33 & 6.29 \\
\hline
\end{tabular}

* shows the significance at $10 \%$; * * shows the significance at $5 \%$; ${ }^{* * *}$ shows the significance at $1 \%$.

The tables shows the results of bivariate EGARCH model the investigate the volatility spillovers from Industrial production (IP), Consumer price index (CPI), Exchange rate (ER), and Global economic policy uncertainty (GEPU) to the Stock market returns (SP). All the variables are calculated as the natural log of $\left(\mathrm{V}_{t-}-\mathrm{V}_{t-1} / \mathrm{V}_{t-1}\right)$ where $\mathrm{V}_{t}$ and $\mathrm{V}_{\mathrm{t}-1}$ are the current month and previous month values respectively, of the corresponding variables. $\omega$ is constant of the EGARCH model; $\alpha$ is the coefficient of ARCH term; $\gamma$ shows the leverage effect; $\beta$ is the coefficient of GARCH term. LL shows the log likelihood and SS shows the Schwarz info criteria SIC. The Bivariate EGARCH model is used separately for each macroeconomic factor and each country. $\rho$ measures the spillover effect of a microeconomic factors on the stock returns. The parenthesis are enclosed the $p$-values for each coefficient. 
The GARCH term has also significant influence on conditional volatility in the models of all the macro economic factors except ER. It indicates the persistence of volatility, that is, past volatility is helpful in prediction of future volatility. The coefficient of volatility spillover $\rho$ is positive for IP and CPI but negative for ER and GEPU. However, the coefficients are not statistically significant.

In the context of Malaysia, the coefficient of volatility spillover is positive and significant for the macroeconomic indicator IP. It indicates that increase in volatility of industrial production also increases the volatility of the Islamic stock index. The coefficients of $\mathrm{ARCH}$ term are not significant for all the macroeconomic factors which shows that size of shocks does not influence the conditional volatility of the stock market returns. The coefficients of leverage term are negative but only significant for the model of IP at $10 \%$ level of significance. Negative and significant coefficient of the leverage term represent the asymmetric effect of positive and negative news. Similarly, the GARCH term also significant only for the macroeconomic factor IP.

The results of Turkey slightly differ from the other countries. GEPU has a significant volatility spillover effect on the stock market returns. The coefficient is positive which shows that the increase in volatility of GEPU, increase the volatility of Islamic stock index. However, the remaining macroeconomic factors have no significant volatility spillover effect on the stock market returns. The magnitude of shocks does not influence the conditional volatility of the stock market returns as the coefficients of ARCH terms are not significant for all the macroeconomic factors. However, the GARCH term is negative and significant for all the macroeconomic factors that indicates the volatility is persistent. Leverage or asymmetric effect of positive and negative news exist only for the model of GEPU.

Overall, the results show that the stock market returns of the Islamic stock indices are stable and less likely to influence from the shocks of the macroeconomic factors including Industrial production, Inflation rate, Exchange rate and Global economic policy uncertainty. The volatility spillover effect is also different in the context of different countries. Industrial production has a significant spillover effect on Islamic stock index of Malaysia, Global economic policy uncertainty has a significant spillover effect on the Islamic stock of Turkey, whereas the Islamic stock index returns of the Indonesia does not influence from the macroeconomic factors. It seems likely that Islamic equity stocks have permanent investors that prefer the Islamic stocks and less likely to diagnose the other factors.

The findings contrast to the results of Majid and Yusof (2009), Hussin et al. (2012), and Jamaludin et al. (2017) who documented significant relationship between macroeconomic factors and Islamic stock returns. The differences may be attributed to the methodology selection. Most of the study finds cointegration or used ARDL models. However, the current study uses EGARCH model to find volatility spillover.

The findings suggest that the relationship between macroeconomic factors and Islamic stock market returns also depends on context. The returns of Islamic stock index of Indonesia do not fluctuate with the macroeconomic factors. In the context of Malaysia, industrial production positively influence the volatility of the Islamic index whereas the market returns of the Turkish Islamic stock index are significantly associated with the global economic policy uncertainty. It means the Islamic stock market returns are majorly depends upon on the investor specific factors and institutional specific factors.

\section{Conclusion}

The study investigates the spillovers effects from macroeconomic factors to the stock returns of Islamic indices. The study focuses on emerging economies including Indonesia, Malaysia, and Turkey. Keeping in with the views of the available literature, EGARCH model is used to examine the volatility spillovers effect of macroeconomic factors including industrial production, consumer price index, exchange rate, and global economic policy uncertainty on the Islamic stock market returns. The findings show that the shocks in macroeconomic factors are less likely to transmit into the Islamic stock market returns. The results are also different across the countries. In the context of Malaysia only industrial growth has a significant spillover effect whereas in the case of Turkey only global economic policy uncertainty has significant volatility spillover effect on the stock market returns. Surprisingly, exchange rate and inflation have no volatility spillover effect on the Islamic stock indices of all the three countries. The findings are important for investors and policymakers. They should focus mostly on firms specific and stock market specific factors in making policies and portfolios.

\section{References}

Ajmi, A. N., Hammoudeh, S., Nguyen, D. K., \& Sarafrazi, S. (2014). How strong are the causal relationships between Islamic stock markets and conventional financial systems? Evidence from linear and nonlinear tests. Journal of International Financial Markets, Institutions and Money, 28, 213-227.

Anya, K. (2020). Foreign Investors' Abnormal Trading Behavior in the Time of COVID-19. The Journal of Asian Finance, Economics and Business, 7(9), 63-74. https://doi.org/10.13106/ jafeb.2020.vol7.no9.063 
Arienzo, M., Gan, J., Ernst, F., Qin, S., Bondarenko, S., \& Sedlak, D. (2006). Loss pathways of N-nitrosodimethylamine (NDMA) in turfgrass soils. Journal of Environmental Quality, 35(1), 285-292.

Aysan, A. F., Disli, M., \& Ozturk, H. (2018). Bank lending channel in a dual banking system: Why are Islamic banks so responsive? The World Economy, 41(3), 674-698.

Barberis, N., Shleifer, A., \& Wurgler, J. (2005). Comovement. Journal of Financial Economics, 75(2), 283-317.

Bhattarai, S., Chatterjee, A., \& Park, W. Y. (2019). Global spillover effects of US uncertainty. Journal of Monetary Economics, 114, 71-89. https://doi.org/10.1016/j.jmoneco.2019.05.008

Chen, N. F., Roll, R., \& Ross, S. A. (1986). Economic forces and the stock market. Journal of Business, 59(3), 383-403.

Chen, N. F. (1991). Financial investment opportunities and the macroeconomy. The Journal of Finance, 46(2), 529-554.

El Khamlichi, A., Sarkar, K., Arouri, M., \& Teulon, F. (2014). Are Islamic equity indices more efficient than their conventional counterparts? Evidence from major global index families. Journal of Applied Business Research, 30(4), 1137-1150.

Fama, E. F. (1981). Stock returns, real activity, inflation, and money. The American Economic Review, 71(4), 545-565.

Flannery, M. J., \& Protopapadakis, A. A. (2002). Macroeconomic factors do influence aggregate stock returns. The Review of Financial Studies, 15(3), 751-782.

Gan, C., Lee, M., Yong, H. H. A., \& Zhang, J. (2006). Macroeconomic variables and stock market interactions: New Zealand evidence. Investment Management and Financial Innovations, 3(4), 89-101.

Geske, R., \& Roll, R. (1983). The fiscal and monetary linkage between stock returns and inflation. The Journal of Finance, 38(1), 1-33.

Habib, M., \& Islam, K. U. (2017). Impact of macroeconomic variables on islamic stock market returns: Evidence from NIFTY 50 Shariah Index. Journal of Commerce and Accounting Research, 6(1), 37.

Hamao, Y. (1988). An empirical examination of the arbitrage pricing theory: Using Japanese data. Japan and the World Economy, 1(1), 45-61.

Hammoudeh, S., Mensi, W., Reboredo, J. C., \& Nguyen, D. K. (2014). Dynamic dependence of the global Islamic equity index with global conventional equity market indices and risk factors. Pacific-Basin Finance Journal, 30, 189-206.

Han, L., Liu, Y., \& Yin, L. (2019). Uncertainty and currency performance: A quantile-on-quantile approach. The North American Journal of Economics and Finance, 48, 702-729.

Hardius, U. (2015). Customers Trust on Islamic Banks in Indonesia. Journal of Asian Finance, Economics and Business, 2(1), 5-13. https://doi.org/10.13106/jafeb.2015.vol2.no1.5.
Hassan, K. M., \& Girard, E. (2010). Faith-based ethical investing: The case of Dow Jones Islamic indexes. Islamic Economic Studies, 17(2).

Hassan, M. (2001). Risk, Return and Volatility of Faith-based Investing: The Case of DJIM. In: Fifth Harvard University Forum on Islamic Finance. October.

Hayat, R., \& Kraeussl, R. (2011). Risk and return characteristics of Islamic equity funds. Emerging Markets Review, 12(2), 189203.

Ho, C. S. F., Rahman, N. A., Yusuf, N. H. M., \& Zamzamin, Z. (2014). Performance of global Islamic versus conventional share indices: International evidence. Pacific-Basin Finance Journal, 28, 110-121.

Hussin, M. Y. M., Muhammad, F., Hussin, M. A., \& Razak, A. A. (2012). The relationship between oil price, exchange rate and Islamic stock market in Malaysia. Research Journal of Finance and Accounting, 3(5), 83-92.

Jamaludin, N., Ismail, S., \& Ab Manaf, S. (2017). Macroeconomic variables and stock market returns: Panel analysis from selected ASEAN countries. International Journal of Economics and Financial Issues, 7(1).

Jawadi, F., Jawadi, N., \& Louhichi, W. (2014). Conventional and Islamic stock price performance: An empirical investigation. International Economics, 137, 73-87.

Jeon, J.-H. (2018). The Impact of Asian Economic Policy Uncertainty : Evidence from Korean Housing Market. Journal of Asian Finance, Economics and Business, 5(2), 43-51. https:// doi.org/10.13106/jafeb.2018.vo15.no2.43

Majid, M. S. A., \& Yusof, R. M. (2009). Long-run relationship between Islamic stock returns and macroeconomic variables. Humanomics, 25(2), 127-141. https://doi. org/10.1108/08288660910964193

Maysami, R. C., \& Koh, T. S. (2000). A vector error correction model of the Singapore stock market. International Review of Economics \& Finance, 9(1), 79-96.

McIver, R. P., \& Kang, S. H. (2020). Financial crises and the dynamics of the spillovers between the US and BRICS stock markets. Research in International Business and Finance, 101276. https://doi.org/10.1016/j.ribaf.2020.101276

Naifar, N. (2016). Do global risk factors and macroeconomic conditions affect global Islamic index dynamics? A quantile regression approach. The Quarterly Review of Economics and Finance, 61, 29-39.

Nurodin, U., Lilik, A., \& Zulfikar Bagus, P. (2019). Productivity of Islamic Banks in Indonesia: Social Funds versus Financial Funds. Journal of Asian Finance, Economics and Business, 6(3), 115-122. https://doi.org/10.13106/jafeb.2019.vol6. no3.115

Pearce, D. K., \& Roley, V. V. (1984). Stock prices and economic news. Cambridge, MA: National Bureau of Economic Research. 
Poon, S. H., \& Taylor, S. J. (1992). Stock returns and volatility: An empirical study of the UK stock market. Journal of Banking \& Finance, 16(1), 37-59.

Sakti, M. R. P., \& Harun, M. Y. (2015). Relationship between Islamic stock prices and macroeconomic variables: Evidence from Jakarta stock exchange Islamic index. Global Review of Islamic Economics and Business, 1(1), 071-084.

Shamsuddin, A. (2014). Are Dow Jones Islamic equity indices exposed to interest rate risk? Economic Modelling, 39, 273-281.

Szczygielski, J. J., Brümmer, L. M., Wolmarans, H. P., \& Zaremba, A. (2020). Are macroeconomic factors adequate proxies for systematic influences in stock returns? A South African perspective. Investment Analysts Journal, 1-19.

Talla, J. T. (2013). Impact of macroeconomic variables on the stock market prices of the Stockholm stock exchange (OMXS30). Jonkoping International Business School.

Ulev, S., \& Aydın, M. (2019). The Effects of Market Interest Rate on Islamic Indices: A Heterogeneous Panel Data Analysis of Participation 30 Index Companies. Türkiye Islam Iktisadi Dergisi, 6(1), 35-50.

Wahyudi, I., \& Sani, G. A. (2014). Interdependence between Islamic capital market and money market: Evidence from Indonesia. Borsa Istanbul Review, 14(1), 32-47. 